\title{
A review on bioenergy and biofuels: sources and their production
}

\section{Ubaid Rasool and S. Hemalatha*}

School of Life Sciences, B. S. Abdur Rahman University, Vandalur, Chennai-48, India. *Email: hemalatha.sls@bsauniv.ac.in.

\begin{abstract}
Bioenergy refers to renewable energy produced from biomass. Biomass is any organic material which has stored sunlight in the form of chemical energy. Depleting fossil fuel reserves and growing demand for energy has necessitated the renewed search for alternative energy resources such as plants. Biofuels are an alternative to fossil fuels, which are liquid or gaseous fuels that are derived from biomass sources. Biofuels can be used alone or in combination with other fossil fuels such as petrol. Biofuels are classified into first, second and third generation biofuels. In this review paper, emphasis on the production of biodiesel and bioethanol and how to modify the methods that involve their formation has been carried out. Biodiesel and bioethanol come under first generation biofuels. The first generation biofuels are produced from starch and sugars (bioethanol) and from seed oils (biodiesel). The direct use of vegetable oils and non-edible oils can prove harmful for the diesel engines due to their high viscosity, high density and various other problems that are related to them. So there is a need of converting these sources into biodiesel so that it can be used as a replacement for petroleum based diesel. Another important biofuel, referred to as bioethanol has gained a lot of importance. This review article deals with the conversion of non-edible oils to biodiesel or by modifying the process of transesterification as well as the conversion of sugars to bioethanol by genetic modification of yeast cells and by changing the substrates required for ethanol production by yeast.
\end{abstract}

Keywords: Bioenergy; Biofuels; Biodiesel; Bioethanol; Transesterification; Fermentation.

\section{Introduction}

Bioenergy is defined as a renewable energy that is manufactured from biomass. Organic materials such as trees, plants and waste materials come under the broad area of biomass. Bioenergy has received a great interest during the recent times because of rapid growth of fuel prices, fast fossil fuel depletion, environmental degradation by fossil fuels
Received

March 10, 2016

Accepted

May 2, 2016

Released

June 30, 2016

Open Acess

Full Text Article

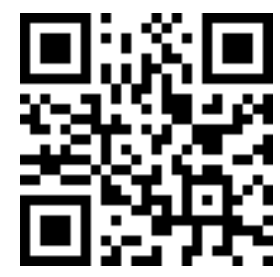

ORCID

() 0000-0002-3311-5280

Ubaid Rasool

(P) 0000-0002-8150-7721

S. Hemalatha and an alteration in global climate. A feedstock refers to a material that serves as the basis for manufacturing another product. For the production of bioenergy, biomass feedstocks serve as key inputs. Biomass feedstocks can be made available from various sources such as agricultural or energy crops, waste fuels, etc. These biomass feedstocks serve as the source of organic matter (Yuan et al., 2008; Zych, 2008; Chum et al., 2011). 


\section{Globe}

\section{Biofuel development across the}

Malaysia and Indonesia are among the largest producers of palm oil in the world and together they produce approximately $80 \%$ of world's palm oil. Biodiesel production in Malaysia relies mainly on palm oil. The flesh of the fruit of palm tree serves as a source of palm oil. According to the records provided by Indonesian Ministry of Energy and Mineral resources, there was a production of about $520,000 \mathrm{t}$ of biodiesel in the year 2007. India has a growing market of ethanol which is more developed than biodiesel market. In the year 2003, Ethanol Blended Petrol (EBP) program was launched in India that sanctioned 5\% ethanol blending with gasoline. Biodiesel production in India is mainly based on non-edible sources because lesser amounts of edible sources are available. Those non-edible sources include jatropha, mahua, karanja, neem, etc. In People's Republic of China (PRC), the major source of ethanol production is corn and around $80 \%$ of ethanol is manufactured from corn. The corn used by PRC mainly includes low-grade corn to avoid competition with food stocks. Nigeria also has a significant potential to produce biofuels from the perspective of available land and wide range of biomass resources. Potential crops for the production of biofuels include cassava, sugarcane, rice and sweet sorghum for bioethanol and for biodiesel the potential crops include palm oil, groundnut and palm kernel. Brazil is also included in the list of those countries that play a role in the development of biofuels. Potential crops that are used to manufacture biofuels in Brazil include physic nut, sunflower, soybean, castor bean, African palm, cotton, peanut, linseed, sesame, canola, etc. For the introduction of biodiesel in national fuel markets, The Federal Government of Brazil has formulated the laws that authorize the use of biodiesel (Körbitz et al., 2003; Sembiring and Kenawas, 2013; Nyachaka et al., 2013; Lopes and Steidle Neto, 2011). Figure 1 shows the global production of biodiesel and ethanol from the year 2000 to 2010.

\section{Bioenergy products}

Taking modern bioenergy into account, the major products of bioenergy are biodiesel and bioethanol. These two major bioenergy products can be used as a replacement for the transportation fuels, hence are referred to as biofuels. Ethanol has certain other uses such as it can be used

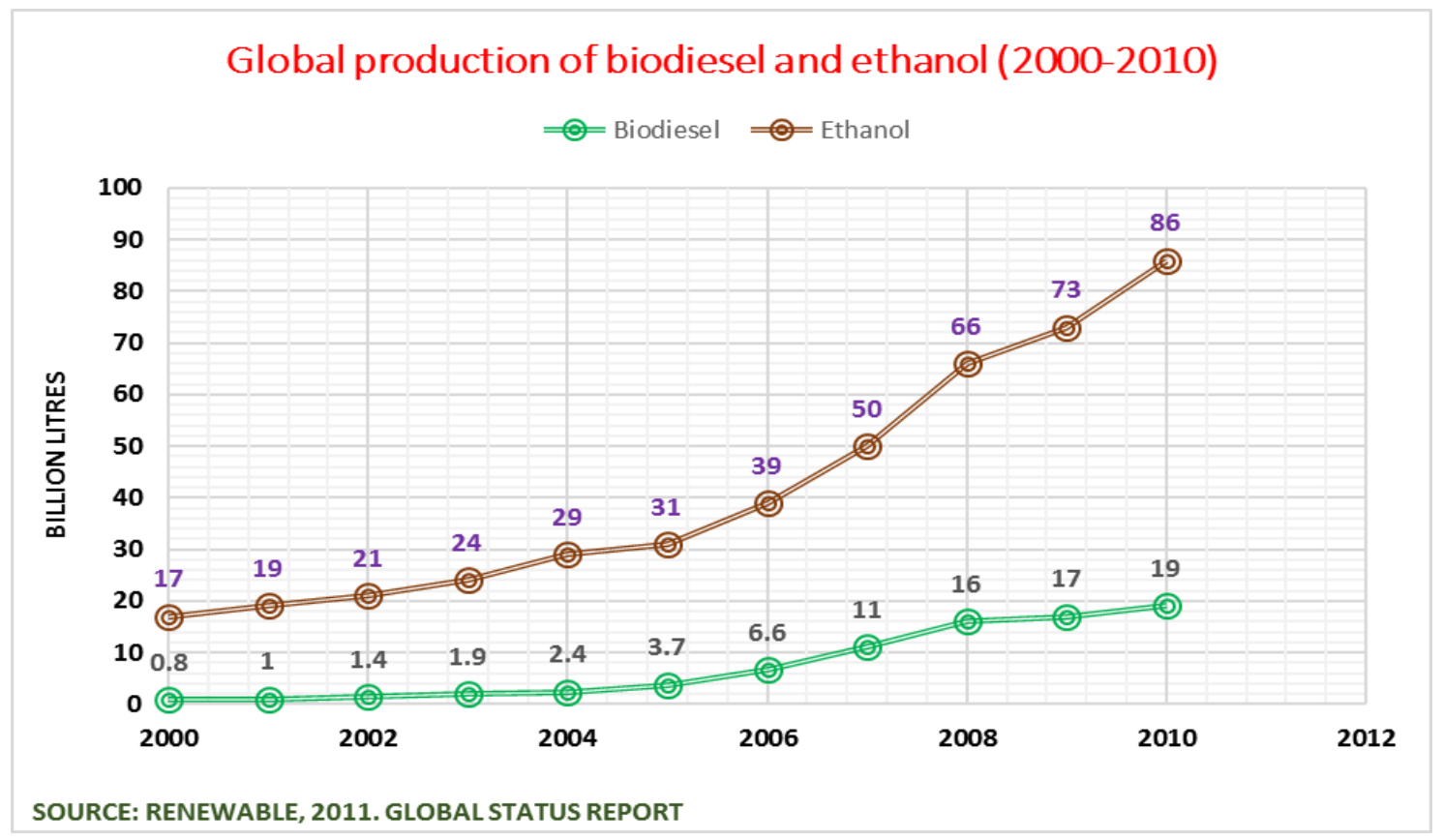

Figure 1. Global production of biodiesel and ethanol (in billion litres) from the year 2000 to 2010. 
as a raw material for various chemical reactions and thus has an importance in chemical industries.

Ethanol is produced by yeast cells through the fermentation of carbohydrates. Fermentation is defined as a process that takes place in the absence of oxygen. This process is carried out by cells and results in the yielding of energy. Ethanol and $\mathrm{CO}_{2}$ are the two by-products that are produced by yeast cells and ethanol serves as a valuable source of energy. Ethanol has gained a significant interest in recent years because it can serve as an alternative to fossil fuels. Moreover, ethanol can help in reducing environmental pollution and is a renewable fuel, thus is advantageous over fossil fuels in various aspects. Ethanol can be blended with gasoline to give rise to gasohol which can serve as an alternative to petroleum based fuels. Ethanol can also help in reducing greenhouse gas emissions particularly in the form of $\mathrm{CO}_{2}$. Ethanol is also a carbon neutral fuel, meaning that the $\mathrm{CO}_{2}$ released upon ethanol burning equals the levels of $\mathrm{CO}_{2}$ uptake by plants from the atmosphere. The production of ethanol has enormously increased in recent years because of its advantageous nature when compared to petroleum based fuels (Demirbaş, 2008).

Biodiesel has also been paid greater attention in recent years because fossil fuel sources are limited and there is a need to look for alternatives to fossil fuels to ensure environmental protection and energy security. Biodiesel is non-toxic, renewable and biodegradable and is considered as one of the most alternative fuels for diesel engines. Biodiesel is prepared from various sources including edible oils, non-edible oils, animal fats, legume plants, etc. Use of high quality edible vegetable oils as a feedstock increases biodiesel production cost. An effective way to reduce the cost of biodiesel production is to use inexpensive and non-edible oils as raw materials. For the production of biodiesel, the main process that is used in its production is termed as transesterification. Transesterification is defined as a reaction involving triglycerides and an alcohol as reactants which after reacting lead to the formation of esters and glycerol as products. This reaction takes place in the presence of a catalyst. There is a good range of choice of catalysts that can be used in the process of transesterification including a strong alkali, a strong acid and an enzyme. Using strong alkali as a catalyst has many advantages including the less catalyst requirement during transesterification and a small reaction time (Pushparaj and Ramabalan, 2013).

\section{Sources of bioenergy}

Biomass refers to all biological material from living or recently living organisms that can be burnt, gasified or fermented to produce Bioenergy. Beneficial sources of bioenergy include legume plants, algae, monocot plants, edible and nonedible vegetable oils and animal fat.

source

Legume plants as a bioenergy

Plants belonging to family Leguminosae such as Vachellia nilotica (L.) P. J. H. Hurter \& Mabb. (widely known by the taxonomic synonym Acacia nilotica (Lam.) Wild.) (babool), Dalbergia sissoo Roxb. (Indian rosewood), Peltophorum pterocarpum (DC.) K. Heyne (yellow flame tree), Perkia biglobosa (Jacq.) R. Br. ex G. Don (locust bean), Delonix regia (Boj. ex Hook.) Raf., etc. can be used as a source of carbohydrate. Pods of these plants containing seeds can be used as a source of carbohydrate, which in turn can be used as a substrate in the fermentation process. Upon enzymatic treatment, pods of these plants release significant amounts of reducing sugars. $V$. nilotica (synonym A. nilotica) pods shows the higher production of reducing sugars when treated with $4 \%$ amylase whereas P. pterocarpum shows the lowest yield of reducing sugar at $4 \%$ amylase enzyme (Gulalkayi et al., 2012).

\section{Algae as a bioenergy source}

Microalgae are unicellular or simple multicellular organisms and can be prokaryotic or eukaryotic in nature. Microalgae have the capability to grow 
naturally in fresh or salt waters. Due to the simple cellular structure of microalgae, they can efficiently convert solar energy. Microalgae are considered among the oldest living organisms on our planet earth. Microalgae have a great diversity and there are about 300,000 species of microalgae. Among the wide diversity of microalgae, there are many species having an oil content of about $80 \%$. Microalgae possess the capability to be used as feedstocks for the production of biodiesel (Figure 2). Microalgal biodiesel comes under third generation of biofuels. Microalgae can serve as the energy sources for the production of biodiesel with renewable nature and apart from that microalgal biofuels can help in overcoming the limitations of first and second generation of biofuels (Htet et al., 2013; Saifullah et al., 2014).

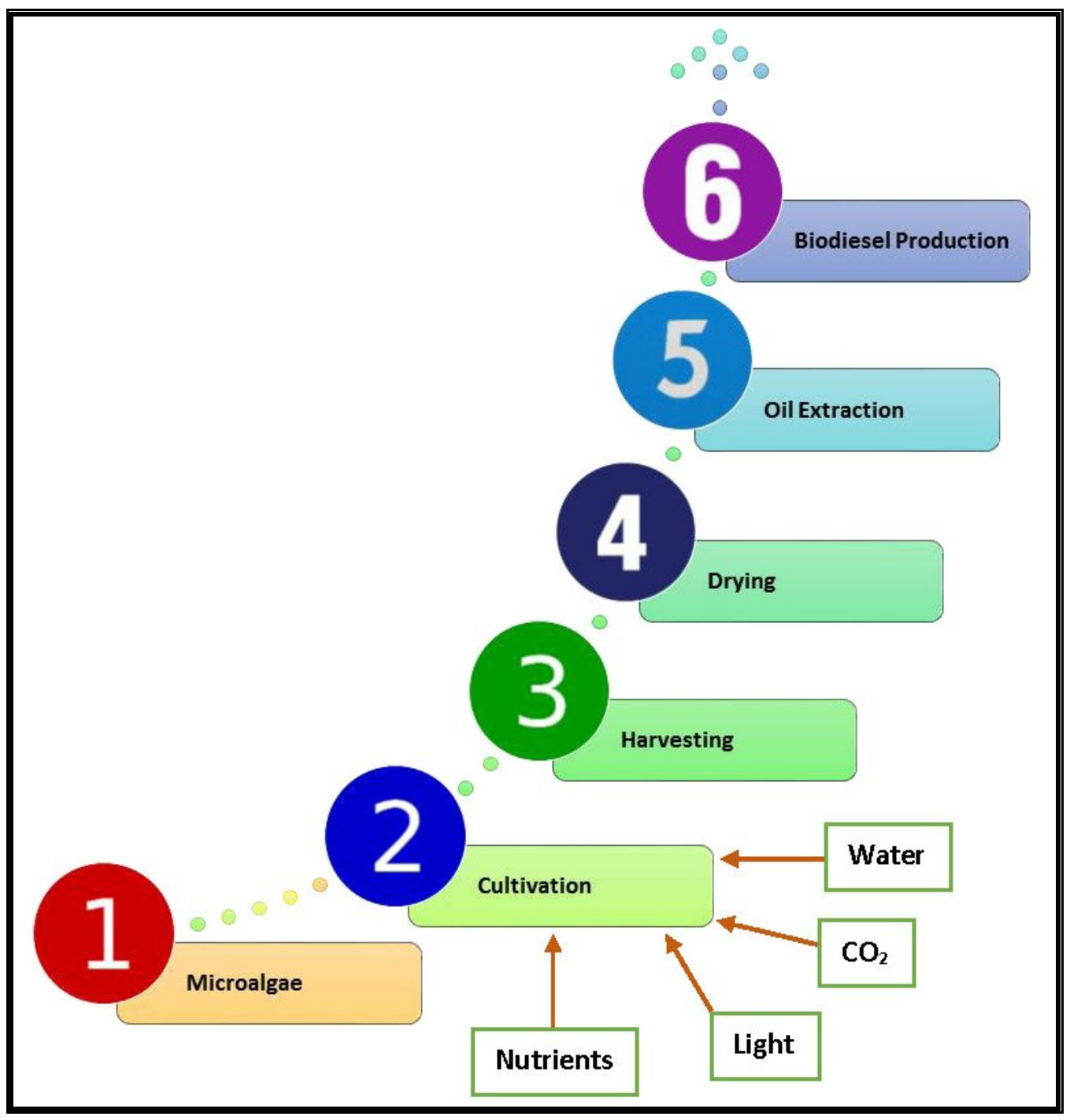

Figure 2. Different stages of production of microalgal biodiesel (Leong et al., 2011; Saifullah et al., 2014).

\section{source \\ Monocot plants as a bioenergy \\ Monocots are those plants that have} a single cotyledon. A variety of monocot plants can be used as a source of bioenergy including corn, maize, wheat, sugarcane, sorghum, miscanthus, etc.

Corn as a bioenergy source. The technology of converting corn into ethanol is a generally known and a familiar 
technology. The conversion of corn to ethanol takes place by the process of fermentation. The yield of ethanol from a large production plant can be around $1 \mathrm{~L}$ from $2.69 \mathrm{~kg}$ of corn grains. For a single growing season, in order to fully irrigate the soil, there is a requirement of almost $100 \mathrm{~cm}$ of water. The average irrigation that is required for the total land during growing season of corn is about $8.1 \mathrm{~cm} / \mathrm{ha}$. Due to high production costs of corn to be used as a feedstock, the best alternative is corn stover. Corn stover refers to the residue that remains on the surface of soil after harvesting the corn grains. The constituents of stover include cob, husks, leaves and stalk fractions. Stover constitutes the coproduct of the high-value corn grain fraction, which explains its abundance. This widespread physical availability could eventually make corn stover a widely used bioenergy commodity. Corn stover's potential applications range from an input in bio- or thermochemical conversion processes for the production of liquid fuels to a direct energy source in biomass cofiring applications. As a cellulosic or second-generation feedstock, corn stover can be used in bioenergy applications without directly affecting food production (Klingenfeld, 2008; Zych, 2008).

\section{Maize as a bioenergy source.}

Maize is one of the largest crops that is cultivated worldwide and it has the property of playing an important role in biofuel development. If maize is to be used for the production of biofuels, then it needs to be cultivated for two purposes viz: for grain production as well as for the production of stem-biomass and that too in higher yields. Because of the availability of resources such as those of agronomic and genomic resources, maize can be cultivated as a dual crop with ease. Due to the presence of all these qualities and availability of resources, maize can be considered as a best model crop for biomass quality in the field of research (Weijde et al., 2013).

Wheat as a bioenergy source. Wheat has the potential to become a major biofuel crop. Using fermentation as a process to produce ethanol from wheat provides a fuel that can be used to run vehicles. Wheat comes under the category of C3 species of plants i.e. plants performing C3 photosynthesis. These species of plants have enough potential of accumulating carbon dry mass which provides enough biomass for energy conversion (McKendry, 2002).

Sugarcane as a bioenergy source. Sugarcane comes under one of the most effective crops in the collection of solar energy and its conversion to chemical energy. The potential of sugarcane as a biomass feedstock is widely acknowledged. When sugarcane is given for processing, there is the production of large amounts of sugarcane bagasse which is nowadays used for steam and electricity generation by burning in boilers. If there is an improvement with respect to the technologies used for bioethanol production, it can help in getting an increased amount of bagasse, which can serve various purposes such as electricity generation, a raw material for bioethanol synthesis and can be used for synthesizing various other bio-based products (Cushion et al., 2009; Weijde et al., 2013).

Sugarcane bagasse is a lignocellulosic material. Cellulose, hemicellulose and lignin are the main constituents of lignocellulosic materials. Cellulose is a polymer of glucose and hemicellulose contains glucose, mannose, xylose and arabinose as main constituents. Sugarcane bagasse needs to be processed to yield fermentable sugars which can be further used as a raw material for bioethanol production. For the separation of lignin and hemicellulose from the cellulose that is present in bagasse, there is the need of a pre-treatment step which helps in improving the quality of bagasse and which in turn makes it easier to hydrolyse cellulose (Elbehri et al., 2013).

Sorghum as a bioenergy source. In sorghum, there is the presence of two types of grains namely - sugar type and a biomass type and hence sorghum is considered as a unique species. Also with 
the available genome sequence of sorghum, it opens up opportunities for sorghum as first- and second generation biofuel crop. Forage sorghums have the highest potential to yield biofuels. Sweet sorghum can also be used in the production of biofuels using same techniques that are employed for sorghum. Sweet sorghum provides various advantages over sugarcane in various aspects such as abiotic stress tolerance, resource use efficiency and also due to simpler genetics and annual nature of sorghum. Sorghum can be enhanced as a bioenergy crop by combining the techniques of genetics, agronomic techniques and processing technology (Weijde et al., 2013).

Miscanthus as a bioenergy resource. C4 grasses, particularly the members belonging to genus Miscanthus have been found as potential bioenergy crops and also can be targeted for improvement. The potential of biomass production in Miscanthus is different for different climate types. The only species that is grown commercially in recent years is a triploid hybrid Miscanthus x giganteus. In order to make the crop optimized to varied environmental conditions and to increase the yield, it is important to take the genetic diversity of the genus into account. The potential biomass crops in the genus Miscanthus include Miscanthus sinensis Andersson and Miscanthus sacchariflorus (Maxim.) Franch., each having a wide distribution in Asian Tropical and temperate regions. Miscanthus lutarioriparius L. Liu ex S. L. Chen \& Renvoize, considered as a subspecies of $M$. sacchariflorus and is restricted to one region in China has also the potential to be as a biomass crop. For making Miscanthus as a potential biomass crop, there is a need of domestication of this crop in coming decades (Shouliang and Renvoize, 2006; Robson et al., 2013; Weijde et al., 2013).

\section{Edible vegetable oils as a bioenergy source}

Edible oils have a great potential to be used as a feedstock for the production of biofuels. Palm oil, soybean oil and rapeseed oil represent the main edible oils which are produced worldwide and together they constitute $75 \%$ of the total edible oil production in recent times. Using biodiesel in place of mineral diesel dates back to early 20th century but its usage was in less amounts. In recent years, particularly from 2005 onwards, the use of biodiesel has increased abruptly, in which European Union (mostly France and Germany) contributes heavily in the biofuel development and about $80 \%$ of the world's biofuel produce comes from EU. When coming to biofuel production using edible oils as a raw material, there are many things that need to be taken into consideration, such as the source of the oil used for biofuel production (whether food or non-food crops are used to derive that oil from) as well as the oil composition and how well it can serve the purpose of using it as a feedstock. In spite of the enormous potential that biodiesel possesses, the limitations come on the way in case edible oils as feedstocks because of their growing demands and their high cost (Calle et al., 2009).

\section{Non-edible vegetable oils as a bioenergy source}

Biofuel production using edible oils as a feedstock has certain limitations with respect to their cost and source from which they are derived. So, for this issue to be addressed, there is a need of less expensive feedstocks. Non-edible oils have a great capability to be used as feedstocks for biofuel production particularly biodiesel. Non-edible oils as feedstocks for biodiesel production can help in reducing the cost of biodiesel production. Jatropha, Pongamia, Palm, Mahua, etc. are the various sources that are present in nature in excess amounts and can serve as a great feedstock. When compared to edible oils, these plants are very economical and are readily available in developing countries. Using vegetable oils directly as fuels can become harmful for the engine with respect to fuel atomization, incomplete combustion, engine fouling, etc. In order to decrease the viscosity of vegetable oils and to make them use as fuels, there are several methods available that can carry out this process 
namely: micro-emulsification, pyrolysis, transesterification, etc. For the commercial production of biodiesel, the most commonly used method employed is transesterification because within a shorter reaction time and the use of low temperature and high pressure it gives a high yield (Shikha and Rita, 2012; Liaquat et al., 2012).

\section{Major non-edible tree borne oilseeds (tbos) in India \\ Mahua (Madhuca indica J. F.} Gmel.). Known by the common name as 'Indian butter tree', mahua is found abundantly in tribal areas of India. Seeds of this plant have about $30 \%-40 \%$ of oil content known as mahua oil (Figure 3). In India it is found mostly in the states of Orissa, Chhattisgarh, Jharkhand, Bihar, Madhya Pradesh, and Tamilnadu.

Jatropha (Jatropha curcas L.). Growing well in marginal or poor soils, $J$. curcas has been investigated as a drought-resistant and a semi-evergreen shrub producing seeds that contain around $37 \%$ oil (Figure 4). The oil derived from Jatropha seeds known as Jatropha oil can be straight away used as a fuel without the process of refining. As a fuel, Jatropha oil has been successfully tested for simple diesel engine and it burns with clear smokefree flame (Ahmad et al., 2013).

Karanja (Millettia pinnata (L.) Panigrahi). M. pinnata is a non-edible oil plant and is of Indian origin. It is widely distributed in tropical Asia. It is generally found in the Western Ghats of India, northern Australia, and Fiji and in some regions of Eastern Asia. This tree bears pods which change their colour from green to tan within a period of almost 10 months. The pods contain brown red shaped kernels resembling the shape of a kidney. When these kernels are air-dried, an oil content of around 27.5\% (Figure 5) can be extracted from them (Padhi and Singh, 2011).

Neem (Melia azadirachta L.). Neem belongs to Meliaceae Family. It grows in tropical and semi tropical regions and is native to India and Burma. This tree can attain a height of around 15-40 $\mathrm{m}$ and it grows fast. The fruits of this plant are ovoid in shape and they possess kernels (one kernel for each seed). The seed kernels of neem tree have a good content of fat (ranges from 33\%-45\%) (Figure 6). Neem oil can be used for other purposes such as soaps, medicines and insecticides (Mehra et al., 2014; Atabani et al., 2013).

Fatty acid composition (\%) of mahua oil (Kulkarni et al., 2013).

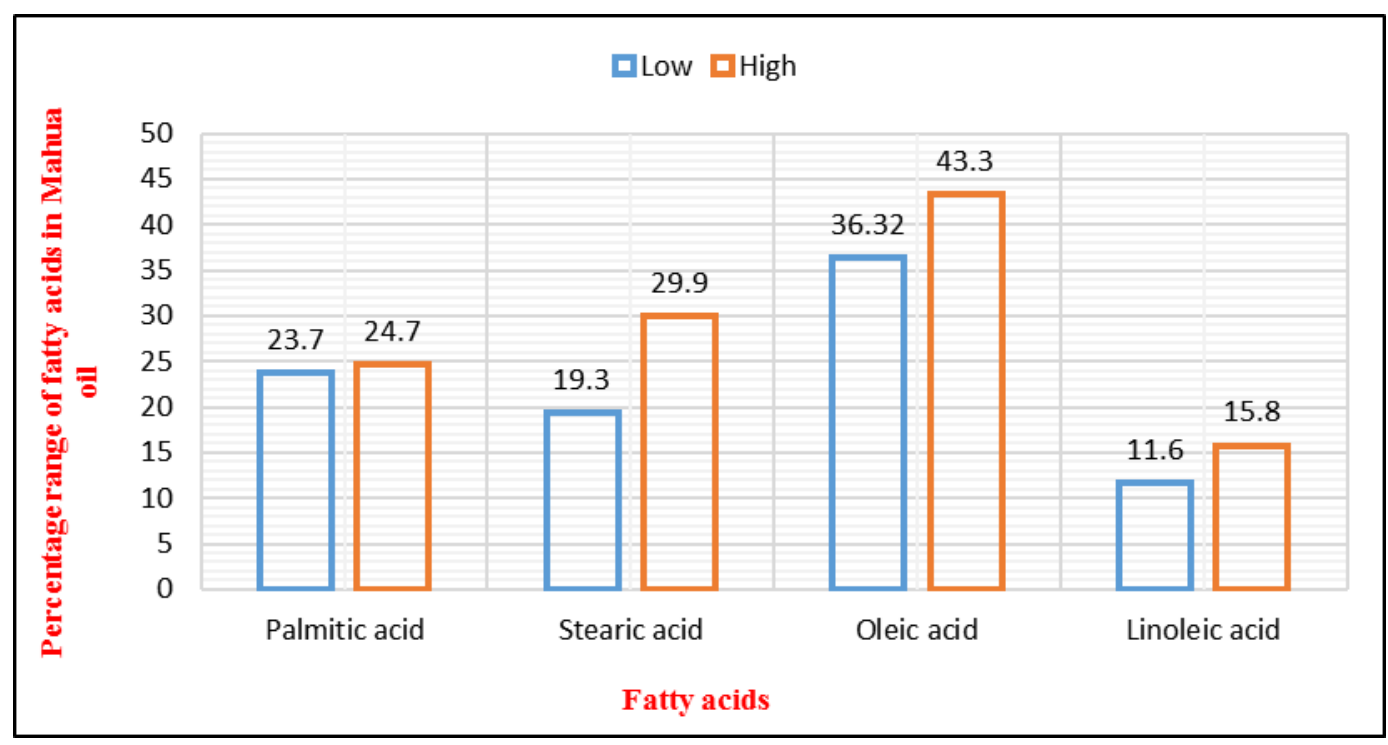

Figure 3. Graphical representation of percentages of different fatty acids in mahua oil. 
Fatty acid composition (\%) of jatropha oil (Akbar et al., 2009).

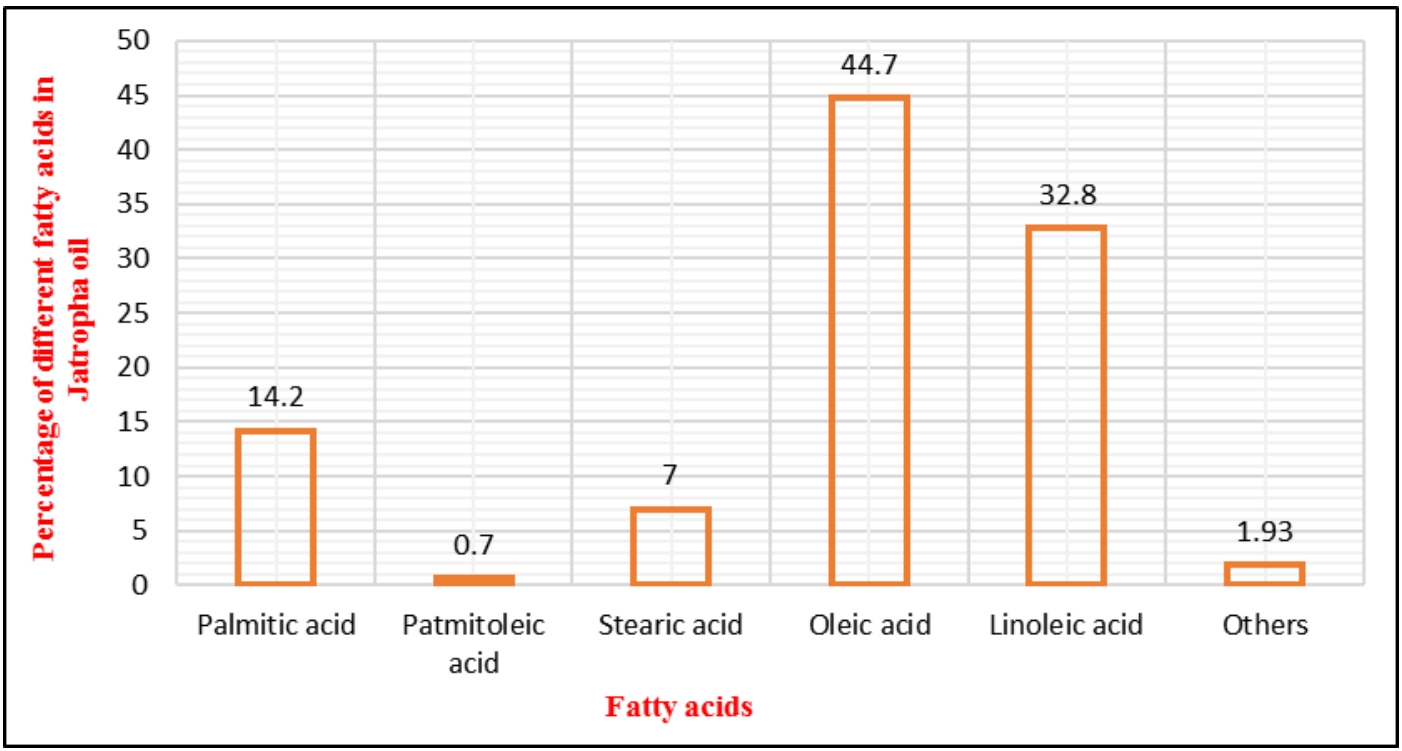

Figure 4. Graphical representation of percentages of different fatty acids in jatropha oil.

Fatty acid composition (\%) of karanja oil (Bobade and Khyade, 2012).

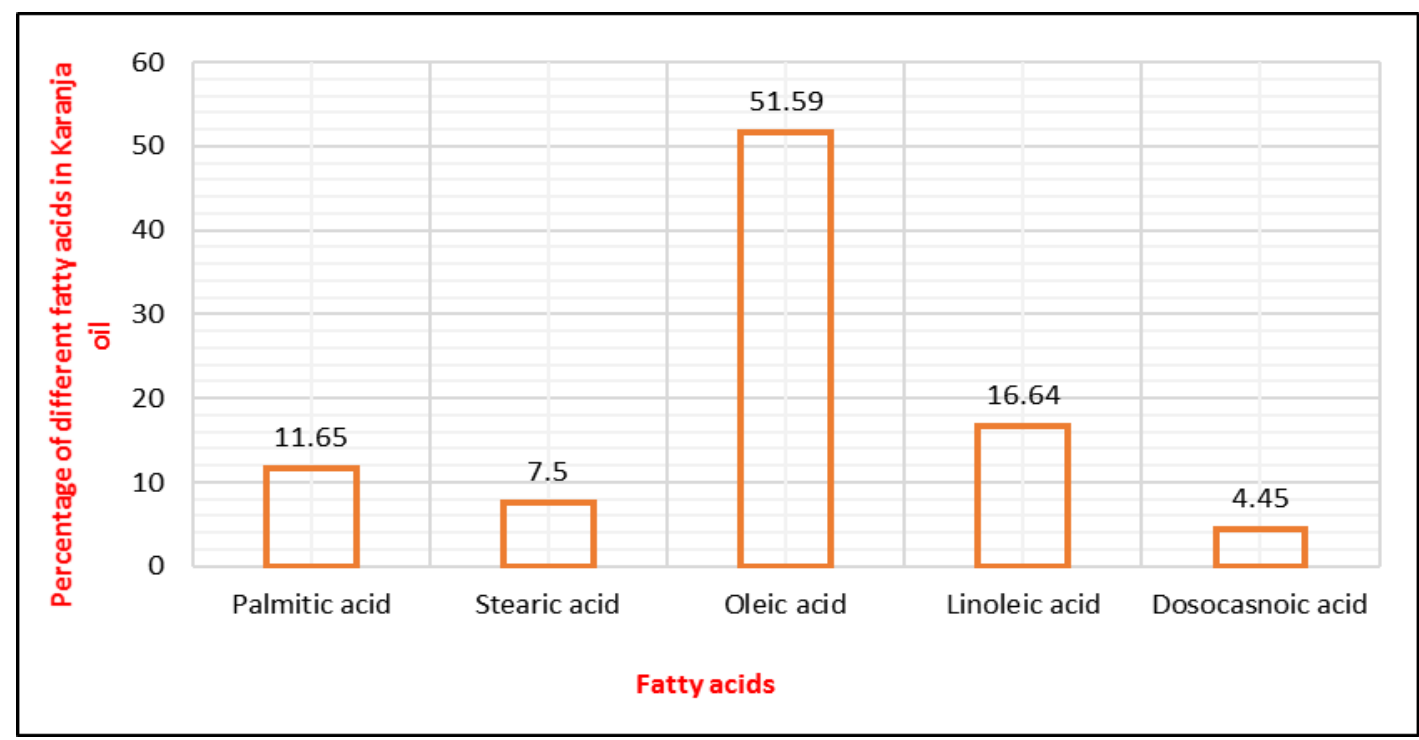

Figure 5. Graphical representation of percentages of different fatty acids in karanja oil. 
Fatty acid composition (\%) of neem oil (Sandanasamy et al., 2013).

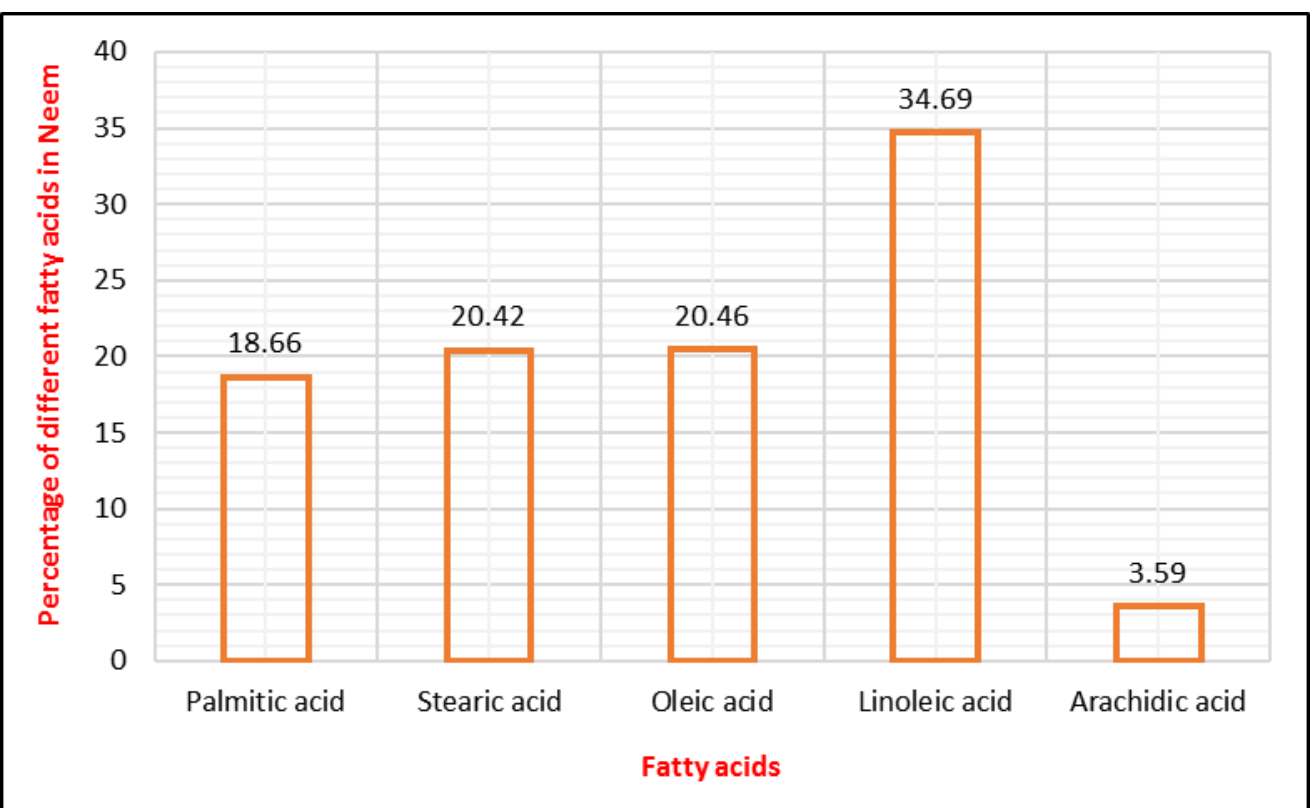

Figure 6. Graphical representation of percentages of different fatty acids in neem oil.

Animal fat as a bioenergy source

The main issue that comes in the way of biodiesel production is the choice of feedstocks. In recent times, inedible animal fats are gaining a lot of interest as the source of lipids. Animal fats can be utilized as biofuel feedstocks. Animal fats as biofuel feedstocks serve two purposes viz: their need for disposal gets eliminated and they also contribute for biodiesel production. Animal fats are easily available feedstock sources. Biodiesel that is derived from virgin oils such as soyabean oil is more resistant to cold weather when compared to the biodiesel derived from animal fat (Ahmad et al., 2011).

\section{Modification of the chemical process to increase the efficiency of products}

For the production of biodiesel, transesterification is utilized and for the production of bioethanol, fermentation is

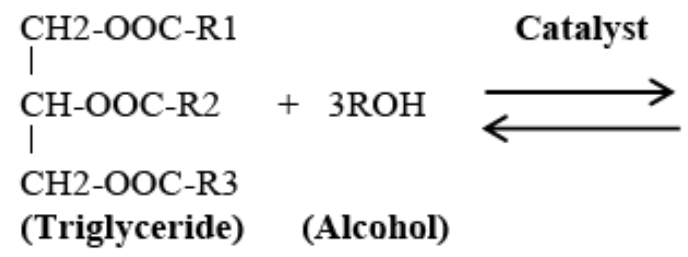

used. Transesterification is also called as alcoholysis, and proceeds via a similar mechanism as hydrolysis and involves the replacement of one alcohol from an ester by another alcohol. The main difference between transesterification and alcoholysis is that in transesterification an alcohol is used instead of water (Singh et al., 2013). Fermentation is the process of conversion of carbohydrates into an alcohol or an acid with the help of an organism. Fermentation is a metabolic process in which starch or a sugar is used as a carbohydrate. For example, conversion of sugar into alcohol by yeast to obtain energy is an example of fermentation. The conversion of carbohydrates into lactic acid by bacteria is another example of fermentation (Helmenstine, 2014).

\section{Transesterification process}

The transesterification reaction can be shown as:

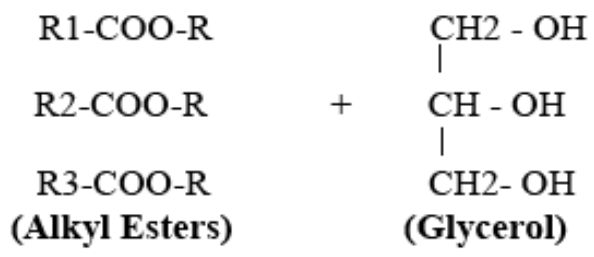


Transesterification is a reversible reaction which yields products upon reactant mixing. This reaction is accelerated by the presence of a catalyst which can be a strong acid or a strong base.

Mostly, an alkali is used in the process of transesterification when biodiesel is to be produced commercially; while as different other methods have been given which involve using acid as a catalyst (Canakci and Gerpen, 1999) or an enzyme as a catalyst (Shah et al. 2003). Acid catalysed transesterification has been found to be fruitful for pre-treating those feedstocks with high contents of free fatty acids, but the speed with which the conversion of triglycerides takes place is very slow. Feedstocks with high free fatty acid contents can be converted to desired products using enzymes but enzymes are expensive and are not able to meet the demands as per ASTM fuel specification (ASTM D6751-15ce1, 2008). Enzyme immobilization and the sequential use of multiple enzymes may prove to be helpful in this area (Kaieda et al., 1999; Watanabe et al., 2000).

Transesterification reaction can by carried out by using either homogeneous or heterogeneous catalysts. Homogeneous alkaline catalysts are useful in obtaining high yields and biodiesel conversion at moderate temperature, atmospheric pressure and brief reaction time. The problem with homogeneous catalysts is that they get dissolved fully in glycerin layer and partially in biodiesel making the purification of product difficult (Graboski and McCormick, 1998). Some homogenous catalysts including sodium hydroxide and potassium hydroxide are toxic (Helwani et al., 2009). To overcome this problem, the development of heterogeneous catalysts came into being. Heterogeneous catalysts have an advantage over homogeneous catalysts in that they are not more sensitive to the presence of free fatty acids and they can be easily removed from reaction mixture and then regenerated and reused. The major problem with heterogeneous catalysts is that the rate of reaction is slow when compared with homogeneous catalyst driven process. This problem is due to three phase reactant formation (methanol/oil/ solid catalyst) (Niju et al., 2014). Therefore, for the transesterification process to proceed optimally there is a need to identify a perfect catalyst which will make the reaction to proceed under mild reaction conditions and short reaction time.

\section{Modifying the process of transesterification}

The process of transesterification involves the reaction between a triglyceride and an alcohol molecule to give alkyl esters and glycerol as reaction products. This process proceeds under the influence of catalyst which helps to speed up the reaction. Transesterification is based on various parameters and by controlling those parameters, a high yield of methyl esters can be obtained. Those parameters include amount of catalyst, alcohol to oil ratio, reaction temperature and reaction time. By changing these parameters, a high yield of methyl esters can be obtained. For example, white bivalve clam shells used as a catalyst in transesterification process show that $7 \mathrm{wt} \%$ catalyst (depending on weight of oil), a molar ratio of 12:1 (methanol to oil ratio), $65{ }^{\circ} \mathrm{C}$ as the reaction temperature and a reaction time of $1 \mathrm{~h}$ are required to obtain a maximum methyl ester conversion of $94.25 \%$ (Niju et al., 2014). Another example involving the alkaline transesterification of neem oil occurs at different values of transesterification parameters such as methanol to oil ratio of $0.3: 1,1 \%$ of $\mathrm{KOH}$ as a catalyst, reaction temperature of $55^{\circ} \mathrm{C}$ and a reaction time of $1 \mathrm{~h}$. Under these set of values, a high yield of biodiesel can be obtained (Sathya and Manivannan, 2013). So, by changing the values of different parameters, the transesterification reaction can be modified to get better results.

\section{Alternative methods of biofuel production}

Apart from the process of transesterification used for the production of biodiesel, there are various other techniques which are used to produce 
biofuels. Some of the important techniques are listed hereunder.

\section{Biodiesel production using the microwave process}

Microwave radiations are a type of electromagnetic radiations having a frequency range of $0.3-300 \mathrm{GHz}$. The electromagnetic spectrum of microwaves lies between those of infrared waves and radio waves (Gude et al., 2013).

Unlike conventional methods, heating by microwave radiations involves rapid heating and generation of heat within the materials. Due to rapid heating, organic reactions involving heating through microwaves get accelerated. Therefore, higher yields can be obtained in a very short reaction time (Quitain et al., 2011).

Biodiesel production using microwaves has been produced from feedstocks having high contents of free fatty acids including jatropha oil. This process offers an easy and fast way to produce biodiesel and moreover the reaction rate and the separation process gets improved (Shakinaz et al., 2010)

The process of transesterification used for the production of biodiesel is a well-known technology but due to the high costs of heating methods that are employed for the manufacturing of biodiesel result in high production costs. Using organic feedstocks in the process of transesterification, biodiesel can be produced using following methods:

a) Heating with acid, base catalysts and co-solvents conventionally (Freedman et al., 1984; Srivastava and Prasad, 2000; Kaieda et al., 2001; Meher et al., 2004).

b) Sub- and supercritical methanol conditions with co-solvent and

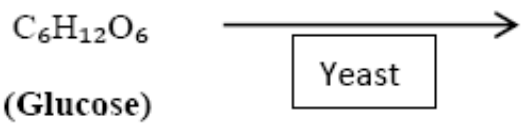

without catalyst (King et al., 1999;

Kusdiana and Saka, 2001; Demirbaş, 2002, 2003, 2005).

c) Enzymatic process employing lipases (Dossat et al., 1999; Hsu et al., 2004; Deng et al., 2005), and

d) Microwave irradiation process using acid, base and heterogeneous catalysts (Ipsita and Gupta, 2003; Ayas and Danisman, 2007).

Among these methods, transesterification by microwaves is energy efficient and a quick process to get biodiesel from different feedstocks (Mazzocchia et al., 2006; Refaat et al., 2008).

Production of bioethanol through yeast fermentation

Bioethanol is simply an ethanol and is defined as a renewable source of energy which is derived from fermentation of sugar and starch components of plants. Agricultural products such as corn, sugarcane, potatoes, rice, etc can be used as a source to produce bioethanol. Bioethanol comes under the first generation of biofuels and its processing is extremely well-defined because it is the most widely used biofuel. Bioethanol production involves following steps: pre-treatment, hydrolysis, detoxification, fermentation and distillation. Fermentation is defined as the chemical transformation of an organic substance into a simpler compound by enzymes. This process is carried out by making use of yeasts and bacteria. Any raw material containing sugar as a major constituent is converted to an alcohol by yeast fermentation (Vikash et al., 2013; Wong and Sanggari, 2014).

Yeast fermentation reaction of glucose can be shown as:

\section{(Carbon dioxide)}

Braz. J. Biol. Sci., 2016, v. 3, no. 5, p. 3-21. 


\section{Enhancing biofuel production by making use of ultrasound waves}

Ultrasound waves have a positive impact on biofuel production as they can increase the efficiency of lignocellulosic biomass by efficiently removing lignin in solution. In plant cell walls, lignin is the chemical compound that binds to cellulose and hemicellulose. Usually, to remove lignin, enzymes are used and the freed sugars get dissolved for further biofuel processing. Using ultrasound waves, there is an increase in efficiency of removing lignin and sugar dissolution takes place rapidly. Pre-treating lignocellulosic biomass with ultrasound makes sugar dissolution rapid. Even, untrasonics can increase the hydrolysis of corn starch that is further processed for fermentation (Priyanka, 2008).

\section{Role of genetic engineering in bioenergy}

Genetic engineering plays an important role in the development of bioenergy crops and thus helps in the production of biofuels. Using biotechnology to genetically improve the crop species and mixing genetic methods with conventional breeding methods can be used to modify the traits. Furthermore, the modification of traits helps in the improvement of bioenergy crops. Trait modification with respect to biofuels such as production of cellulases and other hydrolytic enzymes, increase in cellulose contents and decrease in lignin contents can help in increased production of biofuels (Kausch et al., 2010). Role of genetic engineering with respect to following aspects can be taken into account:

\section{Cell wall manipulation}

The cell wall of plants consists of different polymers that are heterogeneously mixed to form a complex system of polymers. The quality of cell walls is determined by the presence of various complex polymers and their interaction among themselves. Lignin constitutes an essential component of plant cell walls and upon industrial processing of cell walls, lignin adds up to the cell wall recalcitrance. In order to make the cell wall of plants to be used for bioenergy feedstock development, modifying and reducing the lignin content plays an important role (Bosch and Hazen, 2013).

Upon lignin modification, i.e. reducing the content of lignin in plant cell walls, there is not any increase in pathogen susceptibility but in some cases lignin modification has resulted in an increased resistance to pathogens (Sattler and Harris, 2013).

The key components of cell wall include cellulose, hemicellulose, pectin and lignin. The conversion of these cell wall polysaccharides into fermentable sugars can be carried out through enzymatic hydrolysis involving cellulases and hemicellulases. These enzymes can be produced in sufficient amounts using genetic engineering techniques (Sticklen, 2008).

\section{Lignin availability}

Lignin is one of the most abundant aromatic polymers present in plant cell walls in major amounts. Lignin is composed of monolignols such as pcoumaryl, coniferyl and sinapyl alcohols. Lignin availability in plant cell walls makes them resistant to enzymatic degradation and moreover lignin has a less commercial value and plays a role only as a source of heat, therefore lignin is usually treated as a waste product (Hamelinck et al., 2005; Vanholme et al., 2010).

Presence of lignin in plant biomass reduces its digestibility and by combining with other polymers such as cellulose and hemicellulose barriers the way of biofuel processing. Enzymes responsible for the synthesis of monolignols are highly conserved in vascular plants. Genetic engineering techniques have been developed that can help in removing the lignin contents. Removal of lignin from plant cell walls comes with deleterious effects because lignin cannot be simply removed but some genetic manipulations have been carried out that moderately reduce the lignin contents and thus help in improving biomass digestibility (Baucher et 
al., 2003; Umezawa, 2003; Weng et al., 2008).

\section{Cellulose}

Cellulose is the most abundant biopolymer in the world. It is a polysaccharide and is the largest reservoir of organic carbon on earth. Globally, 180 billion tons of cellulose are produced by plants per year. In primary cell walls of plants, cellulose makes up to $15-30 \%$ of dry mass while as in secondary cell walls, it makes up to $40 \%$. Lignocellulosic biomass plays an important role in plants as it helps to fight against pathogens and insects and helps to direct the plant with respect to its structure. Cell wall is an important source of lignocellulosic biomass. The secondary cell wall of plants consists of cellulose, hemicellulose and lignin. Cellulose is embedded in lignin but is less rigid (Goldschmidt, 2008; Sticklen, 2008).

\section{Pectin}

In monocots and dicots, pectin is a major component of plant cell walls. In primary cell walls of dicots, pectin constitutes a fundamental component. In nongraminaceous monocots, pectin accounts for $30 \%-35 \%$ of dry weight. In secondary cell walls of plants and in some grasses pectin is present in rich amounts. Pectin is a linear polymer with rich amounts of galacturonic acid in which homogalacturonan accounts for about 65\% of pectin (Mohnen, 2008).

For the production of efficient biofuels from raw feedstocks, the proper optimization methods for extraction and degradation of pectin are necessary (Fissore et al., 2011; Min et al., 2011).

Use of raw materials for biofuel production that are rich in lignocellulose, there is a need to improve their conversion efficiency and same goes for pectin which needs proper methods to increase its conversion efficiency. This can be overcome by the use of proper molecular and genetic engineering methods (Xiao and Anderson, 2013).

\section{Advantages and disadvantages of biofuels}

Biofuels are defined as the fuels that have been derived from plants and crops (biomass sources). The most important biofuels are biodiesel and bioethanol. Fuels derived from plants come under renewable source and can be grown anywhere. Compared to fossil fuels, biofuels have lower carbon emissions. Biofuels even help in reducing the emission of greenhouse gases. However, biofuels have their own advantages and disadvantages (Uppangala, 2010; Skye, 2012) which are briefly summarized as follows:

\section{Advantages}

1) Biofuels are a renewable source of energy and hence are better than fuels derived from fossils because fossil fuel resources are limited.

2) Biofuels are environment friendly as compared to petroleum based fuels because the burning of biofuels causes less environmental pollution.

3) Major problem in burning a fossil fuel is that a high content of sulphur is released into the atmosphere leading to the formation of acid rain. Burning a biofuel also releases levels of nitrogen into the atmosphere, but on a whole the net acid rain production is greatly reduced by using biofuels.

4) Production of biofuels should be carried in a proper way because proper biofuel production can greatly help in the reduction of greenhouse gas emissions.

5) Biofuels can be produced from various inexpensive sources, including wastes from crops, used vegetable oils, non-edible oils, animal fats, etc. 


\section{Disadvantages}

1) Biofuels release large quantities of carbon upon burning.

2) Bioenergy crops are those crops that are required for the production of biofuels. As the demand for these crops will increase, it can lead to an increase in food prices.

3) There is a great concern about the valuable crop-land used for biofuel production. There can be shortages of food if crops are grown for the production of biofuels.

4) For the proper maintenance of biofuel crops, water is required in large quantities which can put a strain on available water resources.

5) The energy output of biofuels is lower than that of petroleum based fuels, so in order to attain the same energy levels, biofuels need to be used in large quantities.

\section{Conclusion}

Biofuels are a best alternative to petroleum based fuels because of their best combustion profile and environment friendly nature. Moreover, the feedstocks that are required to synthesize biofuels can be obtained easily. Biofuels have an advantage over petroleum fuels because biofuels can be produced from waste products such as used vegetable oils as well as less expensive sources including nonedible oils such as neem oil, jatropha oil, etc. Biofuels can also be produced using algae and fungi as raw materials. The renewable nature of biofuels makes them better than normal petrol and diesel and hence biofuels can be used in place of fossil fuels which are not renewable. In spite of such advantages of biofuels over petrol and diesel, there are a lot of disadvantages related to them but the overall effects of biofuels are advantageous over normal petrol and diesel. Many countries including India, Brazil, Indonesia, etc. are participating in this field of manufacturing biofuels. Use of biofuels also provides advantageous to engines because their lubricating property is enhanced using biofuels.

Biofuels mainly include biodiesel and bioethanol which are produced by the processes named as transesterification and fermentation respectively. Using different raw materials in fermentation process, the ethanol yield can be increased and by modifying the transesterification process the biodiesel yield can be increased. Molecular and genetic engineering techniques can also be used to enhance the biofuel yield. Making genetic alterations in the raw materials that are used for biofuel production can prove fruitful. Different alternative techniques have been developed that can be used for the production of biofuels including microwave irradiations, ultrasounds, etc.

In short, biofuels can provide a useful way to reduce the dependency on non-renewable fossil fuels as well as can prove beneficial to the environment around us.

\section{Acknowledgements}

The authors are greatly thankful to B. S. Abdur Rahman University for providing all the research facilities.

\section{Conflict of interest statement}

Authors declare that they have no conflict of interests.

\section{References}

Ahmad, M.; Khan, M. A.; Zafar, M.; Sultana, S. Biodiesel from non-edible oil seeds: a renewable source of bioenergy. In: Bernardes, M. A. S. (Ed.). Economic effects of biofuel production. Rijeka, Croatia: InTech, 2011. Available from: <http://cdn.intechopen.com/ pdfs-wm/17887.pdf $>$. Accessed in: Feb. 18, 2016. 
Ahmad, M.; Teong, L. K.; Sultana, S.; Zafar, M. Biodiesel production from non-food crops: a step towards self reliance in energy. In: Vilas, A. M. (Ed.). Materials and processes for energy: communicating current research and technological developments. Badajoz, Spain: Formatex Research Center, 2013. p. 239-243. Available from: <http://www.formatex.info/ energymaterialsbook/book/239-243.pdf $>$.

Accessed in: Feb. 18, 2016.

Akbar, E.; Yaakob, Z.; Kamarudin, S. K.; Ismail, M.; Salimon. J. Characteristic and composition of Jatropha curcas oil seed from Malaysia and its potential as biodiesel feedstock. European Journal of Scientific Research, v. 29, no. 3, p. 396, 2009. Available from: <http://www.doc-developpement-durable. org/file/Huiles-vegetales-noix/Fiches_plantes/ jatropha/Characteristic and Composition of Jatropha Curcas Oil Seed_Malaysia.pdf $>$. Accessed in: Feb. 18, 2016.

ASTM D6751-15ce1. Standard specification for biodiesel fuel blend stock (B100) for middle distillate fuels. West Conshohocken, PA: ASTM International, 2008. (Report no. D6751-08).

Atabani, A. E.; Silitonga, A. S.; Badruddin. I. A.; Mahlia, T. M. I.; Masjuki, H. H.; Mekhilef, S. A comprehensive review on biodiesel as an alternative energy resource and its characteristics. Renewable and Sustainable Energy Reviews, v. 16, no. 4, p. 2070-2093, 2012.

Ayas, N.; Danisman, A. Alkali catalyzed transesterification of cotton seed oil by microwave irradiation. Fuel, v. 86, no. 17/18, p. 2639-2644, 2007.

Babu, V.; Thapliyal, A.; Patel, G. K. Biofuels production. Hoboken, New Jersey: John Wiley \& Sons, 2013.

Baucher, M.; Halpin, C.; Petit-Conil, M.; Boerjan, W. Lignin: genetic engineering and impact on pulping. Crit. Rev. Biochem. Mol. Biol., v. 38, no. 4, p. 305-350, 2003. Available from: <http://www.biotecnologie.univaq.it/ getres.php?resid=467>. Accessed in: Feb. 18, 2016.

Bobade, S. N.; Khyade, V. B. Preparation of methyl ester (biodiesel) from karanja (Pongamia pinnata) oil. Research Journal of Chemical Sciences, v. 2, no. 8, p. 43-50, 2012. Available from: <http://www.isca.in/rjcs/ Archives/vol2/i8/8.ISCA-RJCS-2012-106.pdf>. Accessed in: Feb. 18, 2016.

Bosch, M.; Hazen, P. Lignocellulosic feedstocks: research progress and challenges in optimizing biomass quality and yield. Front Plant Sci., v. 4, article 474, 2013. http://dx.doi.org/10.3389/fpls.2013.00474.

Canakci, M.; Van Gerpen, J. Biodiesel production from oils and fats with high free fatty acids. Transactions of the American Society of Agricultural Engineers, v. 44, no. 6, p. 1429-1436, 1999. Available from: $<$ https://seniordesign.engr.uidaho.edu/2007 2008/frenchfryfuel/paper_2.pdf>. Accessed in: Feb. 18, 2016.

Chand, P. Enhancing biodiesel production from soybean oil using ultrasonics. Ames, Iowa: Iowa State University, 2008. (Graduate dissertation). Available from: $<$ http://lib.dr.iastate.edu/cgi/viewcontent.cgi? article $=2110 \&$ context $=$ etd $>$. Accessed in: Feb. 18, 2016.

Chum, H.; Faaij, A. P. C.; Moreira, J.; Edenhofer, O. Renewable energy sources and climate change mitigation. In: Girardin, L. O.; Roman, M. Special report of the Intergovernmental Panel on Climate Change. Cambridge: Cambridge University Press, 2012. p. 209-331. Available from: $<$ http://rael.berkeley.edu/old_drupal/sites/defaul t/files/IPCC 2011- Special Report on Renewable Energy Sources and Climate Change Mitigation.pdf $>$. Accessed in: Feb. 18, 2016.

Cushion, E.; Whiteman, A.; Dieterle, G. Bioenergy development: issues and impacts for poverty and natural resource management. Washington, DC: The Word Bank, 2009. p.157-161. Available from: <http://siteresources.worldbank.org/INTARD/ Resources/Bioenergy.pdf $>$. Accessed in: Feb. 18, 2016.

Demirbaş, A. Biodiesel from vegetable oils via transesterification in supercritical methanol. Energy Conversion and Management,

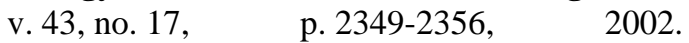
http://dx.doi.org/10.1016/S01968904(01)00170-4

Demirbaş, A. Biodiesel fuels from vegetable oils via catalytic and non-catalytic supercritical alcohol transesterifications and other methods: a survey. Energy Conversion and Management,

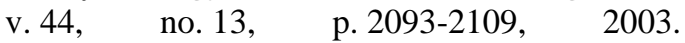
http://dx.doi.org/10.1016/S01968904(02)00234-0.

Demirbaş, A. Biodiesel production from vegetable oils via catalytic and non-catalytic supercritical methanol transesterification methods. Progress in Energy and Combustion Science, v. 31, p. 466-487, 2005. Available from: <http://nopr.niscair.res.in/bitstream/ 
123456789/5379/1/JSIR 64(11) 858-865.pdf>. Accessed in: Feb. 18, 2016.

Demirbaş, A. Biofuels sources, biofuel policy, biofuel economy and global biofuel projections. Energy Conversion and Management, v. 49, no. 7, p. 2106-2116, 2008. http://dx.doi.org/10.1016/j.enconman.2008.02.020

Deng, L.; Xu, X.; Haraldsson, G. G.; Tan, T.; Wang F. Enzymatic production of alkyl esters through alcoholysis: a critical evaluation of lipases and alcohols. J. Am. Oil Chem. Soc., v. 82, no. 5, p. 341-347, 2005.

Dossat, V.; Combes, D.; Marty, A.; Continuous enzymatic transesterification of high oleic sunflower oil in a packed bed reactor: influence of the glycerol production. Enzyme Microb. Tech., v. 25, p. 194-200, 1999.

El Sherbiny, S. A.; Refaat, A. A.; El Sheltawy, S. T. Production of biodiesel using the microwave technique. Journal of Advanced Research, v. 1, no. 4, p. 309-314, 2010. http://dx.doi.org/10.1016/j.jare.2010.07.003

Elbehri, A.; Segerstedt, A.; Liu, P. Biofuels and the sustainability challenge: a global assessment of sustainability issues, trends and policies for biofuels and related feedstocks. Rome: FAO, 2013. Available from: $<$ http://www.fao.org/docrep/017/i3126e/i3126e. pdf $>$. Accessed in: Feb. 18, 2016.

Fissore, E. N.; Ponce, N. M. A.; Matkovic, L.; Stortz, C. A.; Rojas, A. M.; Gerschenson, L. N. Isolation of pectin-enriched products from red beet (Beta vulgaris L. var. conditiva) wastes: composition and functional properties. Food Sci. Technol. Int., v. 17, p. 517-527, 2011.

Freedman, B.; Pryde, E. H.; Mounts, T. L. Variables affecting the yields of fatty esters from transesterified vegetable oils. Journal of Oil \& Fat Industries, v. 61, no. 10, p. 16381643 , 1984.

http://dx.doi.org/10.1007/BF02541649

Goldschmidt, F. From cellulose to ethanol: engineering microorganisms to produce biofuel. Zürich: Institute of Biogeochemistry and Pollutant Dynamics, 2008.

Graboski, M. S.; McCormick, R. L. Combustion of fat and vegetable oil derived fuels in diesel engines. Progress in Energy and Combustion Science, v. 24, no. 2, p. 125-164, 1998.

Gude, V. G.; Patil, P.; Martinez-Guerra, E.; Deng, S.; Nirmalakhandan, N. Microwave energy potential for biodiesel production. Sustainable Chemical Processes, v. 1, article 5, 2013. http://dx.doi.org/10.1186/20437129-1-5
Gulalkayi, V. S.; Unakal, C. G.; Kaliwa, B. B. Biotechnological production of ethanol by Saccharomyces cerevisiae, using different substrates. Journal of Pharmaceutical and Scientific Innovation, v. 1 no. 6, p. 13-17, 2012. Available from: <http://jpsionline.com/ admin/php/uploads/147_pdf.pdf >. Accessed in: Feb. 18, 2016.

Hamelinck, C. N.; Hooijdonk, G. V.; Faaij, A. P. C. Ethanol from lignocellulosic biomass: techno-economic performance in short-, middleand long-term. Biomass and Bioenergy, v. 28, no. 4, p. 384-410, 2005.

Helwani, Z.; Othman, M. R.; Aziz, N.; Kimc, J.; Fernando, W. J. N. Solid heterogeneous catalysts for transesterification of triglycerides with methanol: a review. Appl. Catal. A: Gen., v. 363, no. 1/2, p. 1-10, 2009.

Hsu, A. F.; Jones, K. C.; Fogila, T. A.; Marner, W. N. Continuous production of ethyl esters of grease using an immobilized lipase. J. Am. Oil Chem. Soc., v. 81, p. 749-752, 2004. Available from: <http://naldc.nal.usda.gov/download/ 13885/PDF>. Accessed in: Feb. 18, 2016.

Htet, M. Z.; Ling, L. Y.; Yun, S. H.; Rajee, O. Biofuel from microalgae: a review on the current status and future trends. International Journal of Advanced Biotechnology and Research, v. 4, no. 3, p. 329-341, 2013. Available from: <http://bipublication.com/files/ IJABR-V4I3-2013-08.pdf $>$. Accessed in: Feb. 18, 2016.

Kaieda, M.; Samukawa, T.; Kondo, A.; Fukunda, H. Effect of methanol and water contents on production of biodiesel fuel from plant oil catalyzed by various lipases in a solvent free system. J. Biosci. Bioeng., v. 91, p. 12-15, 2001.

Kaieda, M.; Samukawa, T.; Matsumoto, T.; Ban, K.; Kondo, A.; Shimada, Y.; Noda, H.; Nomoto, F.; Ohtsuka, K.; Izumoto, E.; Fukuda, H. Biodiesel fuel production from plant oil catalyzed by Rhizopus oryzae lipase in a watercontaining system without an organic solvent. Journal of Bioscience and Bioengineering, v. 88, no. 6, p. 627-631, 1999.

Kausch, A. P.; Hague, J.; Oliver, M.; Watrud, L. S.; Mallory-Smith, C.; Meier, V.; Stewart Jr., C. N. Gene flow in genetically engineered perennial grasses: lessons for modification of dedicated bioenergy crops. In: Mascia, P. N.; Scheffran, J.; Widholm, J. M. (Eds.). Plant biotechnology for sustainable production of energy and co-products. Berlin: SpringerVerlag, 2010. (Biotechnology in Agriculture and Forestry, 66). Available from: 
$<$ http://bioenergycenter.org/besc/publications/ kausch_gene_flow.pdf $>$. Accessed in: Feb. 18, 2016.

King, J. W.; Holiday, R. L.; List, G. R. Hydrolysis of soyabean oil in a subcritical water flow reactor. Green Chemistry, v. 1, p. 261264, 1999. Available from: $<$ http://pearl1.lanl.gov/external/c-cde/scf/pubs/ king/137_hydrolosis_of_soybean_oil.pdf $>$. Accessed in: Feb. 18, 2016.

Klingenfeld, D. Corn stover as a bioenergy feedstock: identifying and overcoming barriers for corn stover harvest, storage, and transport. Washington, DC: National Commission on Energy Policy, 2008.

Körbitz, W.; Friedrich, St.; Waginger E.; Wörgetter, M. Worldwide review on biodiesel production. Wieselburg, Austria: IEA Bioenergy Task 39, Subtask “Biodiesel”, 2003. Available from: <http://task39.sites.olt.ubc.ca/ files/2013/05/Korbitz-et-al-2003-WorldwideReview-on-Biodiesel-Production-2003.pdf $>$. Accessed in: Feb. 18, 2016.

Kulkarni, P. S.; Sharanappa, G.; Ramesh, M. R. Mahua (Madhuca indica) as a source of biodiesel in India. International Journal of Scientific \& Engineering Research, v. 4, no. 7, 2013. Available from: <http://www.ijser.org/ paper/MAHUA-MADHUCA-INDICA-AS-ASOURCE-OF-BIODIESEL-IN-INDIA.html>. Accessed in: Feb. 18, 2016.

Leong, S.; Tan, G.; Hao, O. S.; Lim, M. What is Algae Biofuel? In: Leong, S.; Tan, G.; Hao, O. S.; Lim, M. Oil of the future algae? 2011. Available from: <http://www2.hci.edu.sg/ y11hci0149/Website/algae.html >. Accessed in: Feb. 18, 2016.

Liaquat, A. M.; Masjuki, H. H.; Kalam, M. A.; Varman, M.; Hazrat, M. A.; Shahabuddin, M.; Mofijur, M. Application of blend fuels in a diesel engine. Energy Procedia, v. 14, p. 11241133, 2012. Available from: <http://umexpert.um.edu.my/file/publication/ 00006641_78884.pdf $>$. Accessed in: Feb. 18, 2016.

Lopes, D. C.; Steidle Neto, A. J. Potential crops for biodiesel production in Brazil: a review. World Journal of Agricultural Sciences, v. 7, no. 2, p. 206-217, 2011. Available from: $<$ http://www.idosi.org/wjas/wjas7(2)/17.pdf>.

Accessed in: Feb. 18, 2016.

Mazzocchia, C.; Kaddouri, A.; Modica, G.; Nannicini, R. Fast synthesis of biodiesel from triglycerides in presence of microwaves. In: Willert-Porada, M. Advances in microwave and radio frequency processing. Berlin:
Springer, 2006. p. 370-376. (Report from the 8th International Conference on Microwave and High Frequency Heating held in Bayreuth, Germany, September 3-7, 2001. http://dx.doi.org/10.1007/978-3-540-32944-2

McKendry, P. Energy production from biomass (Part 1): overview of biomass. Bioresource Technology, v. 83, no. 1, p. 37-46, 2002. Available from: <http:/faculty.washington.edu/ stevehar/Biomass-Overview.pdf $>$. Accessed in: Feb. 18, 2016.

Meher, L. C.; Vidya Sagar, D.; Naik, S. N. Technical aspects of biodiesel production by transesterification: a review. Renewable and Sustainable Energy Reviews, v. 10, no. 3, p. 248-268, 2004. Available from: <http://eprint.iitd.ac.in/bitstream/2074/1497/1/ mehertec2006.pdf $>$. Accessed in: Feb. 18, 2016. Mehra, K. S.; Shah, M. P.; Singh, S. Use of non-edible vegetable oils as fuel for diesel engine: a review. International Journal for Research in Applied Science and Engineering Technology, v. 2, no. 3, p. 6-11, 2014. Available from: <http://www.ijraset.com/ fileserve.php?FID=693>. Accessed in: Feb. 18, 2016.

Min, B.; Lim, J.; Ko, S.; Lee, K. G.; Lee, S. H.; Lee, S. Environmentally friendly preparation of pectins from agricultural by-products and their structural/rheological characterization. Bioresour. Technol., v. 102, p. 3855-3860, 2011.

http://dx.doi.org/10.1016/j.biortech.2010.12.019

Mohnen, D. Pectin structure and biosynthesis. Curr. Opin. Plant Biol., v. 11, no. 3, p. 266277, 2008.

Niju, S.; Meera Sheriffa Begum, K. M.; Anantharaman N. Enhancement of biodiesel synthesis over highly active $\mathrm{CaO}$ derived from natural white bivalve clam shell. Arabian Journal of Chemistry, in press, 2014. http://dx.doi.org/10.1016/j.arabjc.2014.06.006

Nyachaka, C. J.; Yawas, D. S.; Pam, G. Y. Production and performance evaluation of bioethanol fuel from groundnuts shell waste. American Journal of Engineering Research, v. 2, no. 12, p. 303-312, 2013. Available from: <http://www.ajer.org/papers/v2(12)/ZH2123033 12.pdf $>$. Accessed in: Feb. 18, 2016.

Padhi, S. K.; Singh, R. K. Non-edible oils as the potential source for the production of biodiesel in India: a review. J. Chem. Pharm. Res., v. 3, no. 2, p. 39-49, 2011. Available from: $<$ http://jocpr.com/vol3-iss2-2011/JCPR-2011-32-39-49.pdf>. Accessed in: Feb. 18, 2016. 
Pushparaj T.; Ramabalan, S. Green fuel design for diesel engine, combustion, performance and emission analysis. Procedia Engineering, v. 64, p. 701-709, 2013. http://dx.doi.org/10.1016/j.proeng.2013.09.145

Quitain, A. T.; Katoh, S.; Goto, M. Microwaveassisted synthesis of biofuels. In: Bernardes, M. A. S. (ed.). Biofuel production-recent developments and prospects. Rijeka, Croatia: InTech, 2011. p. 415-436. Available from: $<$ http://cdn.intechopen.com/pdfs-

wm/20069.pdf>. Accessed in: Feb. 18, 2016.

Refaat, A. A.; El Sheltawy, S. T.; Sadek, K. U. Optimum reaction time, performance and exhaust emissions of biodiesel produced by microwave irradiation. International Journal of Environmental Science \& Technology, v. $5, \quad$ no. 3, $\quad$ p. 315-322, 2008. http://dx.doi.org/10.1007/BF03326026

Robson, P.; Jensen, E.; Hawkins, S.; White, S. R.; Kenobi, K.; Clifton-Brown, J.; Donnison, I.; Farrar, K. Accelerating the domestication of a bioenergy crop: identifying and modelling morphological targets for sustainable yield increase in Miscanthus. Journal of Experimental Botany, v. 64, no. 14, p. 41434155, 2013. http://dx.doi.org/10.1093/jxb/ert225

Rosillo-Calle, F.; Pelkmans, L.; Walter, A. A global overview of vegetable oils, with reference to biodiesel: a report for the IEA Bioenergy Task 40. London: Imperial College, 2009. Available from: <http://www.bioenergytrade.org/downloads/ vegetableoilstudyfinaljune18.pdf $>$. Accessed in: Feb. 18, 2016.

Roy, I.; Gupta, M. N. Applications of microwaves in biological sciences. Current Science, v. 85, no. 12, p. 1685-1693, 2003. Available from: <http://www.iisc.ernet.in/ currsci/dec252003/1685.pdf>. Accessed in: Feb. 18, 2016.

Saifullah, A. Z. A.; Karim, Md. A.; AhmadYazid, A. Microalgae: an alternative source of renewable energy. American Journal of Engineering Research, v. 3, no. 3, p. 330-338, 2014. Available from: <http://www.ajer.org/ papers/v3(3)/ZQ33330338.pdf>. Accessed in: Feb. 18, 2016.

Saka, S.; Kusdiana, D. Biodiesel fuel from rapeseed oil as prepared in supercritical methanol. Fuel, v. 80, no. 2, p. 225-231, 2001.

Sandanasamy, J.; Nour, A. H.; Tajuddin, S. N.; Nour, A. Fatty acid composition and antibacterial activity of neem (Azadirachta indica) seed oil. The Open Conference Proceedings Journal, v. 4, Suppl. 2 M11, p. 43-48, 2013. Available from: $<$ http://benthamopen.com/contents/pdf/

TOPROCJ/TOPROCJ-4-2-43.pdf $>$. Accessed in: Feb. 18, 2016.

Sathya, T.; Manivannan, A. Biodiesel production from neem oil using two step transesterification. International Journal of Engineering Research and Applications, v. 3, no. 3, p. 488-492, 2013. Available from: $<$ http://www.ijera.com/papers/Vol3_issue3/ CD33488492.pdf>. Accessed in: Feb. 18, 2016.

Sattler, S. E.; Funnell-Harris, D. L. Modifying lignin to improve bioenergy feedstocks: strengthening the barrier against pathogens. Front. Plant Sci., v. 4, article 70, 2013. Available from: <http://journal.frontiersin.org/ article/10.3389/fpls.2013.00070/full $>$. Accessed in: Feb. 18, 2016.

Sembiring, M.; Yoes, C. K. Fuel price hike and Indonesia's energy insecurity. Singapore: S. Rajaratnam School of International Studies, 2013. (RSIS Commentaries No. 128/2013, 11 July 2013). Available from: $<$ http://econpapers.repec.org/scripts/redir.pf?u= http://www.esocialsciences.org/Download/repec Download.aspx?fname=A2013726172336_20.p df\&fcategory=Articles\&AId=5394\&fref=repec; h=repec:ess:wpaper:id:5394>. Accessed in: Feb. 18, 2016.

Shah, S.; Sharma, S.; Gupta, M. N. Enzymatic transesterification for biodiesel production. Indian Journal of Biochemistry \& Biophysics, v. 40, p. 392-399, 2003. Available from: <http://nopr.niscair.res.in/bitstream/ 123456789/3816/1/IBB 40(6) 392-399.pdf > Accessed in: Feb. 18, 2016.

Shikha, K.; Rita, C. Y. Biodiesel production from non-edible-oils: a review. Journal of Chemical \& Pharmaceutical Research, v. 4, no. 9, p. 4219-4230, 2012. Available from: $<$ http://jocpr.com/vol4-iss9-2012/JCPR-2012-49-4219-4230.pdf>. Accessed in: Feb. 18, 2016.

Shouliang, C.; Renvoize, S. A. 188. MISCANTHUS Andersson, Öfvers. Kongl. Vete nsk.-Akad. Förh. 12: 165. 1855. Flora of China, v. 22, p. 581-583, 2006. Available from: $<$ http://flora.huh.harvard.edu/china/PDF/ PDF22/Miscanthus.pdf $>$. Accessed in: Feb. 18, 2016.

Singh, S.; Jain, M.; Pal, A. Use of biodiesel in CI engines: a review'. International Journal of Innovative Research in Science, Engineering and Technology, v. 2, no. 6, p. 2465-2469, 2013. Available from: <http://www.ijirset.com/ upload/june/21A_Use of Biodiesel.pdf $>$. Accessed in: Feb. 18, 2016. 
Skye, J. Advantages and disadvantages of biofuels. Green living-alternative fuel. Burlingame, CA: LoveToKnow, 2012. Available from: $<$ http://greenliving.lovetoknow.com/Advantages _and_Disadvantages_of_Biofuels $>$. Accessed in: Feb. 18, 2016.

Srivastava, A.; Prasad, R. Triglycerides-based diesel fuels. Renewable and Sustainable Energy Reviews, v. 4, no. 2, p. 111-133, 2000.

Sticklen, M. B. Plant genetic engineering for biofuel production: towards affordable cellulosic ethanol. Nature Reviews Genetics, v. 9, p. 433-443, 2008. Available from: <https://www.tamu.edu/faculty/tpd8/BICH407/ cellwalleng.pdf>. Accessed in: Feb. 18, 2016.

Umezawa, T. Diversity in lignan biosynthesis. Phytochem. Rev., v. 2, p. 371-390, 2003. http://dx.doi.org/10.1023/B:PHYT.0000045487. 02836.32

Uppangala, N. Advantages and disadvantages of biofuels. Biotech Articles, Environmental Biotechnology. 2010. Available from: $<$ http://www.biotecharticles.com/Environmental -Biotechnology-Article/Advantages-andDisadvantages-of-Biofuels-163.html>. Accessed in: Feb. 18, 2016.

van der Weijde, T.; Alvim Kamei, C. L.; Torres, A. F.; Vermerris, W.; Dolstra, O.; Visser, R. G.; Trindade, L. M. The potential of C4 grasses for cellulosic biofuel production. Front. Plant Sci., v. 4, article 107, 2013. Available from: $<$ http://journal.frontiersin.org/article/10.3389/ fpls.2013.00107/full $>$. Accessed in: Feb. 18, 2016.

Vanholme, R.; Demedts. B.; Morreel, K.; Ralph, J.; Boerjan, W. Lignin biosynthesis and structure. Plant Physiol., v. 153, no. 3, p. 895-905, 2010. Available from:
$<$ http://www.plantphysiol.org/content/153/3/ 895.full.pdf>. Accessed in: Feb. 18, 2016.

Watanabe, Y.; Shimada, Y.; Sugihara, A., Noda; H., Fukuda, Tominaga, Y. Continuous production of biodiesel fuel from vegetable oil using immobilized Candida antarctica lipase. Journal of Oil \& Fat Industries, v. 77, no. 4, p. 355-360, 2000. <http://lib3.dss.go.th/fulltext/ Journal/J.AOCS/J.AOCS/2000/no.4/apr2000vol 77,no4,p355-360.pdf $>$. Accessed in: Feb. 18, 2016.

Weng, J.-K.; Li, X.; Bonawitz, N. D.; Chapple, C. Emerging strategies of lignin engineering and degradation for cellulosic biofuel production. Curr. Opin. Biotechnol., v. 19, no. 2, p. 166-172, 2008. Available from: <https://www.tamu.edu/faculty/tpd8/BICH407/ sdarticle1.pdf>. Accessed in: Feb. 18, 2016.

Wong, Y. C.; Sanggari, V. Bioethanol production from sugarcane bagasse using fermentation process. Orient J. Chem., v. 30, no. 2, p. 507-513, 2014. Available from: <http://www.orientjchem.org/pdf/vol30no2/ OJCV030I02P507-513.pdf $>$. Accessed in: Feb. 18, 2016.

Xiao, C.; Anderson, C. T. Roles of pectin in biomass yield and processing for biofuels. Front. Plant Sci., v. 4, Article 67, p. 1-7, 2013. Available from: <http://www.ncbi.nlm.nih.gov/ pmc/articles/PMC3608898/pdf/fpls-0400067.pdf $>$. Accessed in: Feb. 18, 2016.

Yuan, J. S.; Tiller, K. H.; Al-Ahmad, H.; Stewart, N. R.; Stewart Jr., C. N. Plants to power: bioenergy to fuel the future. Trends in Plant Science, v. 13, no. 8, p. 421-429, 2008.

Zych, D. The viability of corn cobs as a bioenergy feedstock. University of Minnesota, 2008. http://dx.doi.org/10.3389/fpls.2013.00067 